TRAMES, 2021, 25(75/70), 1, 19-35

\title{
WHY THEY CHOOSE A TEACHING CAREER? FACTORS MOTIVATING CAREER CHOICE AMONG ESTONIAN AND FINNISH STUDENT TEACHERS
}

\author{
Merle Taimalu $^{1}$, Piret Luik ${ }^{1}$, Ritva Kantelinen ${ }^{2}$, and Jari Kukkonen ${ }^{2}$ \\ ${ }^{1}$ University of Tartu and ${ }^{2}$ University of Eastern Finland
}

\begin{abstract}
There are problems with the recruitment and retention of teachers in many countries. Several factors in the environment can influence these decisions. The current study compared factors that motivated Estonian and Finnish student teachers in their career choice, including perceptions about teaching work. Confirmatory factor analyses were performed on a sample of 718 Estonian and 322 Finnish students and measurement invariances were tested. The results with latent means comparison revealed six significant differences between the countries in terms of motivational factors; Estonian respondents gave higher ratings for all of them. As for perceptions, satisfaction with choice, status and salary were rated higher by Finnish student teachers, while expertise, social dissuasion and difficulty of the work were rated higher by Estonian students.
\end{abstract}

Keywords: teaching career, career choice motivation, perceptions, student teachers, crossnational comparison

DOI: https//doi.org/10.3176/tr.2021.1.02

Received 5 May 2020, accepted 22 October 2020, printed and available online 10 March 2021

\section{Introduction}

In Europe and elsewhere, emphasis is increasingly put on teaching work, teacher education and initial motivations, and the problems of recruitment and retention of teachers. Good teachers are considered one of the crucial factors for the success of students and satisfaction with their school (Müller, Alliata, and Benninghoff 2009). The state of teacher education varies from one European country to another. In some 
countries - Albania, Denmark, Estonia, Latvia, Portugal (OECD 2018a) - teaching is not a popular choice among young people, and these countries are faced with a lack of teachers. In other countries - Cyprus, Finland, Greece, Ireland, Poland (Carlo et al. 2013), Algeria, Korea, Luxembourg, Thailand and others (OECD 2018a) - the teaching profession is more popular. In addition, in many countries young people with higher achievements and men do not choose teaching or do not want to work as a teacher for a long time (OECD 2018c).

Comparative approach is necessary because of globalisation, as teacher education has expanded across regional and national boundaries (König and Rothland 2017). There are few comparative studies (e.g. König and Rothland 2017, Reimer and Dorf 2014) on countries that are culturally more similar. We have chosen two countries for our research, Estonia and Finland. Estonia and Finland are quite similar in terms of culture and teacher-education, nonetheless the teaching profession is valued quite differently in these societies. This allows focus on potentially different motivations that may result from differences in how the teaching profession is valued across those setting and how teachers are educated. It is useful for policy makers to know what attracts young people to teaching so they can plan how to get more and better candidates into teacher education and how to retain good teachers in the profession.

\subsection{Previous cross-cultural studies on the career motivation of student teachers}

It is necessary to explore career decisions in context because several factors in the environment can influence these decisions (Uztosun and Topkaya 2017). There is quite a low number of cross-cultural comparative studies exploring why student teachers have entered teacher education. We have found single comparative studies which include countries from one continent and quite similar contexts; for example, the EU countries Finland and Denmark (Reimer and Dorf 2014), and Germany, Austria and Switzerland (König and Rothland 2017), Finland and Germany (Goller, Ursin, Vähäsantanen, Festner and Harteis 2019). But most comparative studies have used samples from quite contrasting cultures; for example, pre-service teachers in the USA and China (Lin et al. 2012); Australia and Germany (Beltman and Wosnitza 2008); Canada and Oman (Klassen et al. 2011), Australia, United States, Germany and Norway (Watt et al. 2012); and Germany, Japan, and Turkey (Uztosun and Topkaya 2017).

Regardless of whether those cultural contexts are similar or different, similarities and differences in the factors impacting teaching career choice are always found. Japanese respondents reported lower perceived teaching ability and external factors, and teaching as a fallback career higher than the other respondents (Uztosun and Topkaya 2017). According to the results from the study by Watt et al. (2012) motivations were quite similar, but perceptions of the work of a teacher were much more context-sensitive (or culturally sensitive). According to the study by König and Rothland (2017), where student teachers' evaluations in Switzerland, Germany and Austria were compared, it seems that both motivations and perceptions were similarly evaluated in all countries. Reimer and Dorf (2014) concluded that both Finnish and 
Danish student teachers chose teacher education because of the status and high respect for the teaching profession, but Finnish students valued social aspects of teaching career and educational content more than Danish students, while their Danish counterparts valued family compatibility higher than the Finns (Reimer and Dorf 2014). Researchers have found that Canadian student teachers were more self-oriented than other-oriented when compared with Omani student teachers (Klassen et al. 2011).

In perceptions about the work of teachers US students have given higher ratings for expertise demanded, teaching being perceived as more difficult, but with higher social status, and were also more satisfied with their choice than Chinese students (Lin et al. 2012). In the case of German and Swiss teachers, salary rated higher than in other countries, obviously because the salary for teachers in these countries is higher (Watt et al. 2012). German participants had more negative perceptions about teaching as a well-respected and valued career by society than Japanese and Turkish respondents (Uztosun and Topkaya 2017). Also, German students scored higher on the fallback career factor than Finnish participants, and their career choices were influenced more strongly by extrinsic motivations, e.g., salary, time for family, job security (Goller et al. 2019).

When conducting studies in different cultures, the suitability of the instrument and data comparability are crucial issues. Out of the above mentioned seven studies, only Lin et al. (2012) and Watt et al. (2012) used confirmatory factor analysis and measurement invariance, respectively. As different measurement scales were used in different comparative studies, we have chosen the FIT Choice framework, which has been validated in many countries. This scale has been found suitable for comparative studies about motivations for choosing teaching career and its measurement invariance has been found acceptable in different cultures and contexts.

\subsection{FIT Choice framework for investigation of teaching motivations}

The basic theoretical framework for this study is expectancy-value theory, as the theory on what the FIT Choice framework has been developed (see Watt, Richardson and Smith 2017). This theory discusses a person's ability, beliefs and values, how much they expect success and subjective task values, which can all have an impact on a person's choices (e.g. why they have decided to become a teacher). According to this theory, both positive and negative task characteristics that have an impact on an individual's choices are included. Based on this theory Watt and Richardson have developed FIT-Choice scale (see Richardson and Watt 2007) measuring teacher motivation, which consists of three parts: motivations to choose teaching, perceptions about teaching profession, and satisfaction with the choice.

Motivations were divided into subcomponents: intrinsic value, personal utility value, social utility value. Intrinsic value included items about the respondent's wishes and interest in a teacher's career. Personal utility value included values considered as important by the individual. These included time for family, job security and job transferability. Social utility value included, for example, the desire to serve society, work with children, make social contribution, etc. Also motivations were added for the prior teaching and learning experiences, social influences, and the negative 
motivation to choose teaching as a fallback career. In perceptions part there were two main subcomponents - task return and task demand. The first included three aspects such as social status, teacher's morale and salary. The second consisted of two aspects - expert career and high demand. Also items to measure the experience of social dissuasion and satisfaction with the choice were added (Kilinç, Watt and Richardson 2012, Watt and Richardson 2007, 2012).

We have used this framework for our study. The FIT-Choice Scale has been used in many previous studies and validated in different contexts, including Estonia (see e.g. Goller et al. 2019, Kilinç et al. 2012, Nesje, Brandmo and Berger 2018, Taimalu, Luik and Täht 2017, Watt and Richardson 2012).

\subsection{Context of education and working as a teacher in Estonia and Finland}

Several similarities and differences could be identified between these two countries selected in the study in the field of education. The following will discuss similarities in teacher education and the teaching profession.

Both countries have initiated and are in the process of delivering educational reforms and changes (Curriculum reform 2016, Estonian Lifelong Learning strategy 2020 2014). In Estonia one goal is to bring competent and motivated teachers to work in schools (Estonian Lifelong... 2014). This also includes improving the position of teachers in the society and investigating teacher motivation. In both countries, the educational system is built on a network of comprehensive schools and follows the principle of equality (PISA 2015 tulemuste... 2016, Niemi, Toom and Kallioniemi 2016). Estonia and Finland are both recognised internationally for the high quality of their educational systems and for achieving excellence in education. Both countries enjoy high positions in PISA results (OECD 2018b). This quality is often seen as resulting from the high quality of the teachers (e.g. Niemi 2016, PISA 2015 tulemuste... 2016). Schools and teachers have a high level of autonomy (Niemi et al. 2016, PISA 2015 tulemuste... 2016).

In both countries, teachers are prepared through university level and are required to have a master's degree or equivalent, except for Estonian kindergarten and vocational teachers, and Finnish kindergarten teachers, who are required to have a bachelor's degree (Asetus opetustoimen henkilöstön ... 986/1998, Direktori, õppealajuhataja, õpetajate... 2013). Teacher education is strongly research-based in both countries (Sarv 2014, Tirri 2014). Several similar changes in the work of teachers have emerged in both countries. Teachers face similar increases in their duties and responsibilities in the form of cooperative practices with parents (Böök and Perälä-Littunen 2015, Estonian Lifelong... 2014), higher numbers of students with special needs (Inclusive education of ... n.d., Niemi 2016).

Both in Estonia and Finland there is the relatively low number of male teachers and young teachers in schools and kindergartens (OECD statistics 2016). The age structure of teaching staff is also quite similar in both countries. In 2016 (OECD statistics 2016) the average age of Estonian teachers was 48 years and of Finnish teachers 45 years. 
The low salaries of teachers in Estonia has been a hot topic for several years (e.g. Valk 2016) and have increased significantly over the last years. With regard to wages, we can highlight both similarities and differences between the two countries. While the actual salaries of teachers compared to the salaries earned by tertiaryeducated employees in other professions, the ratios are similar - remaining in both Finland and Estonia just below the average salary in positions requiring a similar level of education (OECD statistics 2016). In Finland, teachers' salaries depend on the school level, while in Estonia all teachers with a master's degree have the same minimal statutory starting salary (OECD 2018a).

Although several important similarities were found in the Estonian and Finnish educational contexts, there are also some differences. Teaching has been one of the least preferred occupations among young people in Estonia (Valk 2016). Often the best candidates do not enter teacher education programmes and there are not enough candidates to choose from. In Finland, teaching is a popular career among young people. Only about $10 \%$ to $15 \%$ of all applicants can be accepted into teacher education. This is especially true for primary school and kindergarten levels (Paronen and Lappi 2018). The status of the teaching profession is a widely discussed topic in society. According to the TALIS 2018 survey (Taimalu, Uibu, Luik and Leijen 2019), only $26 \%$ of Estonian teachers compared with $57 \%$ of Finnish teachers perceive that their profession is valued enough by society. Regardless of the above-mentioned differences between teachers in the two countries, quite the same amount $-94 \%$ of Estonian teachers and $88 \%$ Finnish teachers, report they are satisfied with their job (OECD 2020).

\subsection{Aim}

As discussed above the situation in Estonia and Finland concerning the popularity of the teaching career is somewhat different and somewhat similar. Furthermore, insufficient studies have been conducted to obtain information about differences in the motivation between student teachers in the different countries (Reimer and Dorf 2014). However, comparative perspective is important, as with globalization, teacher education has expanded across national borders also (König and Rothland 2017). The question arises, therefore, whether and how the factors influencing the choice of teaching as a career (motivations and perceptions about the work of teachers) differ between the two culturally similar countries where the teaching profession is valued differently.

The aim of this paper is, firstly, to examine the suitability and validity of FITChoice scale for comparison teaching motivations across two different countries, and secondly, to find out and compare the motivations and perceptions of the choice of teaching profession among first-year student teachers in Estonia and Finland. It is important to study first-year student teachers, because the decision to become a teacher is made before entering teacher education, so we get the least impact of teacher education or educators on the results. 


\section{Method}

\subsection{Participants and procedure}

The sample consists of first-year pre-service student teachers from Estonia and Finland. The data were gathered at the beginning of their teacher education courses. The size of the sample was 718 students from Estonia (University of Tartu and Tallinn University) and 322 from Finland (University of Eastern Finland, Joensuu and Savonlinna Campus). The respondents were from different programmes from kindergarten teachers to secondary school teachers. The mean age of the Estonian sample was 25.5 years $(\mathrm{SD}=7.25)$ and the mean age of the Finnish sample was 22.8 years (4.86). From the Estonian respondents $102(14.2 \%)$ and from the Finnish respondents $50(15.5 \%)$ were male.

\subsection{Instruments}

The method of data collection was a questionnaire. The Factors Influencing Teaching Choice (FIT-Choice) Scale was used (Richardson and Watt 2006), which consisted of 40 items on motivation and 20 items on perceptions about the work of teachers and about satisfaction with choice. The original scale was adapted for the Estonian and Finnish context in 2012. All the original items were translated into Estonian and Finnish, and the comprehensibility and cultural compatibility of each item was discussed in the research team and also with the authors of the scale. There was one person in our team who was bilingual (both Estonian and Finnish). The items were subsequently back-translated into English and the items were compared with the original scale. Some items were reworded because of their irrelevancy in the Estonian and Finnish context; for example, the original item in first part: Teaching will be a useful job for me to have when travelling was suitable in the Australian context, but not in the Estonian and Finnish (mainly because of language). Instead of that, we have used two more suitable items from the Turkish study (Kılınç et al. 2012) - Teachers may have the opportunity to work internationally and A teaching certification may enable me to work in European countries. One item (People I've worked with think I should become a teacher) was also left out because the sample consisted of university students that in the Estonian and Finnish cultural context have mostly not had any working experience and so it is impossible for most of them to respond to this item. The questionnaire was piloted with both sub-samples.

The questionnaire used a 7-point scale and the first part (motivations) included numerous response items that each finished the following in a different way: $I$ chose to become a teacher because... and the response options were: 1 - not at all important; 7 - extremely important. The second part - perceptions about teacher work - similarly contained items, where respondents could select the strength of agreement from 1 (not at all) to 7 (extremely). In addition, there were six items for satisfaction with choice and social dissuasion items with response options (question: How much is this true for you...): 1 (not at all); 7 (extremely). The questionnaire ended by collecting the respondents' background information. 


\subsection{Data analysis}

Statistical analyses were carried out using SPSS for Windows version 24.0 and SPSS AMOS version 24.0. Preliminary analysis of the main variables did not detect any missing data or outliers. As the first phase, the factorial structure of motivations and perceptions using a Confirmatory Factor Analysis (CFA) per sample was conducted, to check whether the structure is supported in both samples. The development of the model (CFA) was based on a model used for Estonian sample (Taimalu, Luik, Kantelinen, Niilo and Kukk 2013). From the original 40 motivation items in the questionnaire only 33 with significant loadings to the constructs were selected for building the final model (two-phase development of the CFA model as suggested by Gerbing and Anderson 1988). In the final ten-construct model, some of the 33 measured variables were retained due to their explanatory value even though their loadings were just above the recommended lower limit (0.4) but less than the recommended (0.7) for a good indicator variable fit (Hair, Ringle and Sarstedt 2011).

The goodness-of-fit of the CFA models among the models estimated were evaluated using the following two absolute goodness-of-fit indices: the Chi-Square Test $(\chi 2)$ and the Root Mean Square Error of Approximation (RMSEA). Nowadays, the chi-square statistic is considered to be inappropriate as a sole indicator of the goodness-of-fit of a model due to its limitations (Byrne 2016). Therefore, the use of relative goodness-of-fit indices is also strongly recommended in the case of large samples (Bentler and Bonett 1980). We used the following indices: the Normal Fit Index (NFI), the Comparative Fit Index (CFI) and the Tucker-Lewis Index (TLI). The chi-squared per degree of freedom was also calculated (Kline 2011). The following cut-off points for goodness of fit indices were used: for the RMSEA $\leq .06$ (Hu and Bentler 1999, Byrne 2016), and for the NFI, TLI and CFI $\geq .90$ (Bentler 1992, Byrne 2016).

Measurement invariance is the prerequisite for comparing the differences across groups with the latent means analysis approach (Chen 2007). Therefore factorial invariance was tested in three increasingly restrictive levels (configural, metric and scalar level) as the second phase (Byrne 2016, Chen 2007). First, configural invariance was tested by running individual CFAs in both country samples to ensure whether the basic model structure was invariant across both country groups. The metric level of invariance was tested by constraining the factor loadings to be equivalent across groups. Scalar invariance was tested to check whether the intercepts were constrained to be equal across groups. The chi-square change difference test is too sensitive to reject invariance when the sample size is relatively large (Byrne 2016, Chen 2007, Cheung and Rensvold 2002) therefore we used Cheung and Rensvold's (2002, also Byrne 2016) criteria, small decrease on CFI $(\Delta C F I<0.01)$ supplemented with small increase of RMSEA $(\triangle$ RMSEA $<0.015)($ Chen 2007). The fourth measurement invariance, residual invariance, was not tested, because it is not necessary for meaningful comparisons of group means (Gregorich 2006).

After the invariance tests, the latent mean analysis approach was conducted as the third phase of data analysis to estimate the differences between the motivation and perception factors in the case of Estonian student teachers and in the case of Finnish student teachers. Latent mean analysis was performed by constraining the latent means 
of the Finnish subsample to be zero. In such way the latent means of the Estonian subsample represent the mean differences between the two groups (Byrne 2016).

\section{Results}

\subsection{Confirmatory factor analysis}

Before undertaking the measurement invariance tests, the CFA was separately conducted for the Finnish and Estonian subsamples. Factor loadings of motivational factors range from 0.42 to 0.97 for the Finnish student teachers, and from 0.57 to 0.97 for the Estonian student teachers. Cronbach's alphas were from .78 to .90 in the case of the Estonian data and from .77 to .95 in the case of the Finnish data. The fit indicators were better for Estonian sample than for Finnish sample (Table 1). Also the root mean square error of approximation, RMSEA $=0.053$ for Estonian and 0.058 for Finnish sample, is below the recommended upper limit of 0.06 indicating a good fit (Hu and Bentler 1999). Based on these considerations, we conclude that the CFA-model had a reasonable good fit for both subsamples (Table 1).

Table 1. The measurement model's goodness-of-fit in the case of motivations factors

\begin{tabular}{lccccccc}
\hline & $\begin{array}{c}\text { Chi-square } \\
(\mathrm{df} 447)\end{array}$ & $\mathrm{P}$ & $\begin{array}{c}\text { Chi-square } \\
/ \mathrm{df}\end{array}$ & NFI & TLI & CFI & $\begin{array}{c}\text { RMSEA } \\
{[\text { conf90 }]}\end{array}$ \\
\hline $\begin{array}{l}\text { Finland } \\
(\mathrm{n}=322)\end{array}$ & 933.325 & $<0.001$ & 2.088 & .864 & .909 & .923 & $.058[.053 ; .063]$ \\
$\begin{array}{l}\text { Estonia } \\
(\mathrm{n}=716)\end{array}$ & 1330.478 & $<0.001$ & 2.976 & .905 & .917 & .934 & $.053[.049 ; .056]$ \\
\hline
\end{tabular}

Note: NFI = normed fit index; TLI = Tucker-Lewis Index; CFI = comparative fit index; RMSEA = root mean square error of approximation [with $90 \%$ confidence interval].

Factor loadings of perception factors ranged from 0.37 to 0.98 for the Finnish student teachers, and from 0.41 to 0.96 for the Estonian student teachers.

The only factor with a Cronbach's alpha below .70 was Difficulty of work (alpha $=.57$ ) in the case of the Estonian data. Other Cronbach's alphas for factors were from .75 to .93 in the case of the Estonian data. In the case of the Finnish data, Cronbach's alphas for two factors (Difficulty of work and Social dissuasion) were below .75 (respectively .71 and .73), other Cronbach's alphas for factors were from .70 and .96 in the case of the Finnish data. In order to examine the goodness-of-fit of the confirmatory factor analysis model of perceptions about teaching against the data several indicators of fit were used (Table 2). Altogether the fit indexes were above the suggested lower limit 0.90 for acceptable fit (Bentler 1992), and very near or above the more recent $\mathrm{Hu}$ and Bentler (1999) recommendation 0.95 for very good fit. Also the root mean square error of approximation RMSEA was below the recommended upper limit of 0.06 in the case of both subsamples indicating a good fit (Hu and Bentler 1999). 
Table 2. The measurement model's goodness-of-fit in the case of perceptions factors

\begin{tabular}{lccccccc}
\hline & $\begin{array}{c}\text { Chi-square } \\
(\mathrm{df} 155)\end{array}$ & $\mathrm{P}$ & $\begin{array}{c}\text { Chi-square } \\
/ \mathrm{df}\end{array}$ & NFI & TLI & CFI & $\begin{array}{c}\text { RMSEA } \\
{[\text { conf90] }}\end{array}$ \\
\hline $\begin{array}{l}\text { Finland } \\
(\mathrm{n}=322)\end{array}$ & 260.191 & $<0.001$ & 1.679 & .927 & .962 & .969 & $.046[.036 ; .056]$ \\
$\begin{array}{l}\text { Estonia } \\
(\mathrm{n}=716)\end{array}$ & 422.574 & $<0.001$ & 2.726 & .941 & .947 & .961 & $.049[.044 ; .055]$ \\
\hline
\end{tabular}

Note: NFI = normed fit index; TLI = Tucker-Lewis Index; CFI = comparative fit index; RMSE = root mean square error of approximation [with $90 \%$ confidence interval].

\subsection{Measurement invariance}

As described in previous section the configural invariance test indicates that the structural patterns are similar across both national subsamples (see Table 1 and 2). This implies that the configural model can be a baseline to compare two other restricted models in the invariance hierarchy.

As can be seen from Table 3, at the factor loadings level the invariance was met in the case of motivational factors. However, at the intercepts level the $\Delta \mathrm{CFI}=0.021$ suggests non-invariance. In further analysis, a partial invariance is more closely achieved, when intercepts of items in construct Enhance social equity (item B49. Teaching will allow me to benefit the socially disadvantaged) and in construct Job transferability (item B32. A teaching profession offers me an opportunity to work internationally) are left to be unconstrained.

Table 3. Invariance testing with nested (increasingly constrained) models in the case of motivations factors

\begin{tabular}{lccccccccc}
\hline & $\begin{array}{c}\text { Chi- } \\
\text { square }\end{array}$ & df & $\mathrm{P}$ & $\begin{array}{c}\text { Chi-square } \\
/ \mathrm{df}\end{array}$ & $\mathrm{NFI}$ & $\mathrm{TLI}$ & $\mathrm{CFI}$ & $\Delta$ CFI & RMSEA \\
\hline $\begin{array}{l}\text { Unconstrained } \\
\text { model }\end{array}$ & 2264 & 894 & $<.001$ & 2.533 & .891 & .913 & .930 & & .038 \\
$\begin{array}{l}\text { Factor } \\
\text { loadings } \\
\text { constrained }\end{array}$ & 2372 & 917 & $<.001$ & 2.587 & .886 & .910 & .926 & .004 & .039 \\
$\begin{array}{l}\text { Intercepts } \\
\text { constrained }\end{array}$ & 2801 & 940 & $<.001$ & 2.984 & .865 & .887 & .905 & .021 & .044 \\
$\begin{array}{l}\text { Intercepts } \\
\text { (partial) }\end{array}$ & 2682 & 938 & $<.001$ & 2.860 & .871 & .894 & .911 & .015 & .042 \\
\hline
\end{tabular}

As can be seen from Table 4, at the factor loadings level the invariance was met $(\Delta \mathrm{CFI}=0.003 ; \Delta \mathrm{RMSEA}=0.000)$ in the case of perceptions factors. However at the intercepts level the $\Delta \mathrm{CFI}=0.039$ suggests non-invariance. In further analysis, a partial invariance is closer achieved $(\Delta \mathrm{CFI}=0.013 ; \triangle \mathrm{RMSEA}=0.005)$ when intercepts of items in constructs Expertise (D10. Do you think teaching requires 
high levels of expert knowledge? and D14. Do you think teachers need high levels of technical knowledge?) and in construct Salary item C1. Do you think teaching is well paid? are left to be unconstrained in the model.

Table 4. Invariance testing with nested (increasingly constrained) models in the case of perceptions factors

\begin{tabular}{lccccccccc}
\hline & $\begin{array}{c}\text { Chi- } \\
\text { square }\end{array}$ & df & P & $\begin{array}{c}\text { Chi-square } \\
/ \mathrm{df}\end{array}$ & NFI & TLI & CFI & $\Delta$ CFI & RMSEA \\
\hline $\begin{array}{l}\text { Unconstrained } \\
\text { model }\end{array}$ & 683 & 310 & $<.001$ & 2.203 & .936 & .951 & .964 & & .034 \\
$\begin{array}{l}\text { Factor } \\
\text { loadings } \\
\text { constrained }\end{array}$ & 721 & 324 & $<.001$ & 2.225 & .933 & .950 & .961 & .003 & .034 \\
$\begin{array}{l}\text { Intercepts } \\
\text { constrained }\end{array}$ & 1142 & 338 & $<.001$ & 3.378 & .893 & .903 & .922 & .039 & .048 \\
$\begin{array}{l}\text { Intercepts } \\
\text { (partial) }\end{array}$ & 869 & 335 & $<.001$ & 2.593 & .919 & .935 & .948 & .013 & .039 \\
\hline
\end{tabular}

Table 5. Latent means comparison in the case of motivations and perceptions factors

\begin{tabular}{lcccc}
\hline & Estimate & S.E. & C.R. & P \\
\hline Intrinsic motivation & -.091 & .058 & -1.564 & .118 \\
Enhance social equity & .501 & .103 & 4.856 & $<.001$ \\
Time for family & .363 & .117 & 3.101 & .002 \\
Job security & .082 & .092 & .891 & .373 \\
Social contribution & .191 & .086 & 2.238 & .025 \\
Work with children & .073 & .09 & 0.812 & .417 \\
Positive prior experience & .004 & .11 & .033 & .974 \\
Fallback career & .337 & .074 & 4.577 & $<.001$ \\
Social influence & .393 & .121 & 3.243 & .001 \\
Job transferability & 1.255 & .124 & 10.087 & $<.001$ \\
\hline Social status & -.300 & .082 & -3.666 & $<.001$ \\
Satisfaction with Choice & -.401 & .075 & -5.316 & $<.001$ \\
Expertise & .147 & .062 & 2.378 & .017 \\
Social dissuasion & .489 & .132 & 3.706 & $<.001$ \\
Salary & -.857 & .093 & -9.258 & $<.001$ \\
Difficulty of work & .400 & .054 & 7.382 & $<.001$ \\
\hline
\end{tabular}




\subsection{Latent mean comparisons}

Since the (at least partial) invariance was determined, it was possible to make latent mean construct comparisons. In Table 5 the mean differences are presented when the means of Finnish subsample are set to be zero in the case of motivational and perceptions factors.

\section{Discussion and conclusions}

The aim of this paper was, firstly, to examine the suitability and validity of FITChoice scale for comparison teaching motivations across two different countries. The 10 -factor model for motivations for choosing a teaching career and the 6-factor model for perceptions about the work of a teacher proved to be applicable. The goodness-offit for both models for both countries were acceptable. Also, measurement invariance was at least partially acceptable, so the factor model was suitable for both countries and comparative studies.

For the perceptions, the same factors were identified as in the models from previous studies (e.g. Heinz et al. 2017): Expertise, Difficulty of work, Social dissuasion, Satisfaction with choice, Social status and Salary. However, for the motivations part, despite the fact that the ten-factor structure can also be found in a previous study among German and Austrian pre-service teachers (König and Rothland 2017), the factors were a little bit different in our study. In our study, intrinsic motivation factors Perceived teaching ability and Intrinsic motivation merged into one factor, in the previous study (König and Rothland 2017) these were separate factors. Under extrinsic motivation in our study the factor Job transferability also emerged, which was not reported on in the study by König and Rothland (2017).

Secondly, our aim was to compare motivations and perceptions among firstyear student teachers in Estonia and Finland. Six statistically significant differences emerged between Estonian and Finnish data from the ten motivation factors. It was interesting, because as König and Rothland (2017) compared three German-speaking countries and found only a few significant differences. In our study despite the fact that the countries were culturally similar more than half of the compared factors were statistically different. Lin et al. (2012) have found quite a similar proportion in differences between Chinese and US student teachers.

It is noteworthy that the Estonian student teachers have evaluated all six mentioned motivation factors higher than the Finnish student teachers. We can see a higher impact of several external factors (time for family, job transferability) in the case of Estonian respondents. Maybe one explanation could be the lower status of the teaching profession and lower perceived salary in Estonia than in Finland (see Taimalu et al. 2019). Therefore, the decisions of the Estonian student candidates could be influenced more by other rewards offered by teaching. At the same time external factor Social influence as the influence of significant others was higher rated by Estonian student teachers compared with Finnish, indicating that in Estonia the choice of teaching profession is guided more by others than for Finnish candidates. 
Finnish students seem to be more independent in their decisions, because it is also found previously by Reimer and Dorf (2014) study that Finnish pre-service teachers have valued family influence lower than Danish student teachers.

There are more teachers among Estonians than among Finns who have decided to be a teacher because of altruistic motivations (Enhance social equity, Make social contribution). It can be explained by attitudes or values that the sense of mission is often seen as very influential in the work of Estonian teachers. Until recent years, teachers' salaries in Estonia have been quite low, and it is probably associated to this profession that those who want to do something for society become teachers. Also, given that the Estonian participants were older than their Finnish counterparts, this may be why those Estonian respondents were more altruistic while the Finnish respondents were more individualistic.

Furthermore, the ratings among Estonian participants of the factor Fallback career were also higher than among Finnish student teachers. This is not an unexpected result, as the teaching profession is not particularly popular among Estonian young people (Carlo et al. 2013, Valk 2016), and although there could be a large number of applications for admission in some teacher education curricula, for many students this is not the first preference.

Estonian student teachers evaluated higher than Finnish factor Job transferability, too. Neither Estonians nor Finns can teach freely elsewhere because of their language, compared to teachers from English-speaking countries. In previous studies (Lin et al. 2012), US students have evaluated job transferability higher than students in China, which is a logical result, since English-speaking teachers are needed more widely than Chinese-speaking teachers. Maybe the difference between Estonian and Finnish respondents is because of the widespread trend among Estonians to work abroad, even temporarily.

In the perceptions in our study, all six factors have shown to be context-dependent, because significant differences emerged between the two countries in all factors. We can say that the perception of teacher profession is more positive in the case of Finnish student teachers and more associated with negative attitudes in the case of Estonian student teachers. Finnish student teachers have seen more positive aspects in the work of teachers, evaluating satisfaction with choice, teachers' status in society and teachers' salary higher than Estonians. This is an understandable result because Finnish teacher education purposefully supports and promotes the professional autonomy of teachers and their moral responsibilities, this is also reflected in the trust society has in teachers (Niemi 2016). According to the TALIS 2018 survey (Taimalu et al. 2019), fewer Estonian teachers than Finnish teachers perceived that their profession was valued enough by society.

Estonian student teachers considered teaching more as a difficult job that needs high expertise than Finnish student teachers. Also social dissuasion was rated higher among Estonian respondents, thus these respondents experienced more influence and suggestions by others to choose a different profession than teaching. It might be that Estonian students are influenced more by others in whether or not to choose the profession of a teacher. However, it seems that Estonian participants have given 
higher ratings for aspects indicating that teaching is hard and complicated and not seen by significant others as a good choice. This difference cannot be explained through higher demands on teacher preparation in Estonia. The requirements for teachers are similar in both countries, for example the required level of education. Also teacher education is strongly research based in both countries (Sarv 2014, Tirri 2014), thus, the level of teacher education should not be a reason for differences between Estonian and Finnish students for perceiving the complexity or demands of the teaching profession.

Similarly, the mass media, which prefers to present negative cases and problems rather than good examples of successful teachers, plays a major role in supporting the perceptions about teachers' work as complex and difficult. The negative role of the media and the undermining of the teaching profession's reputation is being talked about in Estonia and more recently also in Finland.

The finding that six from ten motivation factors and all six perception factors showed significant differences between the two countries seems to be in concordance with the conclusions of Watt et al. (2012) according to the comparison of four countries - that perceptions about the work of a teacher seem to be more contextsensitive and motivations more similar through different countries.

As we saw in Finland, more teachers enter the profession and there are more young teachers than in Estonia, we should try to reduce the rate of those candidates who choose teacher education as a fallback career. There has been a lot of talk about salaries for teachers in Estonia, and these have increased steadily, but surely it is important not only to increase external motivations for teachers, but also factors that can influence the intrinsic motivations. For example, try to reduce the demands and responsibilities of teachers, provide effective in-service training so that teachers can feel more confident and develop support systems in order for the teacher to be more able to enjoy their work with children and cope in the context of inclusive education. Also the media should more emphasize the positive aspects of teaching and not focus on the negative stories that 'sell' better. According to TALIS 2018 results (Taimalu et al. 2019) the value of the teaching profession in society perceived by teachers themselves has increased significantly among Estonian teachers during the last five years, but is still remarkably lower than among teachers in Finland.

Finally, the media or teachers themselves should not intimidate young people by creating a negative picture of the daily work of teachers as difficult and exhausting. Instead, they could emphasize the positive elements and the fun that teaching offers - both at the level of the teachers themselves, but also at the teacher education and community level.

We also need to highlight the different size of the groups in the two countries as a limitation in this study. The Estonian participants were also older than their Finnish counterparts. We have used a self-reporting questionnaire, where only the evaluations of participants for certain motivations and perceptions were gathered. 


\section{Disclosure statement}

No potential conflict of interest was reported by the authors.

Addresses:

Merle Taimalu

Institute of Education

University of Tartu

Salme 1a

50103 Tartu, Estonia

E-mail: merle.taimalu@ut.ee

Tel.: +372 5046967

Piret Luik

Institute of Computer Science

University of Tartu

Narva mnt 18

51009 Tartu, Estonia

E-mail: piret.luik@ut.ee

Ritva Kantelinen

School of Applied Educational Science and Teacher Education

University of Eastern Finland

Joensuu, P.O. Box 111

80101 Joensuu, Finland

E-mail: ritva.kantelinen@uef.fi

Jari Kukkonen

School of Applied Educational Science and Teacher Education

University of Eastern Finland

Joensuu, P.O. Box 111

80101 Joensuu, Finland

E-Mail: jari.kukkonen@uef.fi

\section{References}

Asetus opetustoimen henkilöstön kelpoisuusvaatimuksista 986/1998. [Government decree on Teaching Qualification Requirements 986/1998.] Available online at <http://www.finlex.fi/fi/laki/ ajantasa/1998/19980986>. Accessed on 10.07.2019.

Beltman, Susan and Marold Wosnitza (2008) “'You are getting too old, find a man and marry': social aspects of motivation to choose teacher education". Australian Journal of Educational and Developmental Psychology 8, 49-63. 
Bentler, Peter M. (1992) "On the fit of models to covariances and methodology to the Bulletin". Psychological Bulletin 112, 3, 400.

Bentler, Peter M. and Douglas G. Bonett (1980) "Significance tests and goodness of fit in the analysis of covariance structures". Psychological Bulletin 88, 3, 588-606.

Byrne, Barbara M. (2016) Structural equation modeling with AMOS: basic concepts, applications, and programming. London: Routledge.

Böök, Marja L. and Satu Perälä-Littunen (2015) "Responsibility in home-school relations - Finnish parents' views". Children and Society 29, 6, 615-625.

Carlo, Alain, Alain Michel, Jean-Charles Chabanne, Dominique Bucheton, Patrick Demougin, et al. (2013) Study on policy measures to improve the attractiveness of the teaching profession in Europe. [Research Report] EAC-2010-1391, European Commission, Directorate General for Education and Training. Available online at $<$ https://www.researchgate.net/ publication/281159483_Study_on_Policy_Measures_to_Improve_the_Attractiveness_of the Teaching_Profession_in_Europe>. Accessed on 10.07.2019.

Chen, Fang F. (2007) "Sensitivity of goodness of fit indexes to lack of measurement invariance". Structural Equation Modeling 14, 3, 464-504.

Cheung, Gordon W. and Roger B. Rensvold (2002) "Evaluating goodness-of-fit indexes for testing measurement invariance". Structural Equation Modeling 9, 233-255.

Curriculum reform (2016) Available online at <https:/www.oph.fi/english/education_development/ current_reforms/curriculum_reform_2016>. Accessed on 10.07.2019.

Direktori, õppealajuhataja, õpetajate ja tugispetsialistide kvalifikatsiooninõuded (2013) [Qualification requirements of school principal, head teachers, teachers and support specialists.] Available online at < https://www.riigiteataja.ee/akt/130082013005?leiaKehtiv>. Accessed on 15.07.2019.

Estonian Lifelong Learning Strategy 2020 (2014) Available online at $<$ https://www.hm.ee/en/estonianlifelong-learning-strategy-2020>. Accessed on 15.05.2019.

Gerbing, David W. and James C. Anderson (1988) "An updated paradigm for scale development incorporating unidimensionality and its assessment”. Journal of Marketing Research 25, 2 , 186-192.

Goller, Michael, Jani Ursin, Katja Vähasantanen, Dagmar Festner, and Christian Harteis (2019) "Finnish and German student teachers' motivations for choosing teaching as a career. The first application of the FIT-Choice scale in Finland". Teaching and Teacher Education 85, 235-248.

Gregorich, Steven E. (2006) "Do self-report instruments allow meaningful comparisons across diverse population groups? Testing measurement invariance using the confirmatory factor analysis framework". Medical Care 44, 11, S78-S94. doi:10.1097/01.mlr.0000245454.12228.8f.

Hair, Joe F., Christian M. Ringle and Marko Sarstedt (2011) "PLS-SEM: indeed a silver bullet". The Journal of Marketing Theory and Practice 19, 2, 139-152.

Heinz, Manuela, Elaine Keane and Conor Foley (2017) "Career motivations of student teachers in the republic of Ireland: continuity and change during educational reform and 'Boom to Bust' economic times”. In H. M. G. Watt, P. W. Richardson and K. Smith, eds. Global perspectives on teacher motivation, 22-54. Cambridge, UK: Cambridge University Press.

$\mathrm{Hu}$, Li-tze and Peter M. Bentler (1999) "Cutoff criteria for fit indexes in covariance structure analysis: conventional criteria versus new alternatives". Structural Equation Modeling 6, 1, 1-55.

Inclusive education of SEN students and the effectiveness of related support measures (n.d.) Estonian Centre for Applied Research. Available online at $<$ https://centar.ee/en/case-studies/hariduslikuerivajadusega-opilaste-kaasava-hariduskorralduse-uuring/> . Accessed on 15.05.2019. 
Kilinç, Ahmet, Helen M. G. Watt and Paul W. Richardson (2012) "Factors influencing teaching choice in Turkey". Asia-Pacific Journal of Teacher Education 40, 3, 199-226.

Klassen, Robert M., Said Al-Dhafri, Wanwisa Hannok, and Shea M. Betts (2011) "Investigating preservice teacher motivation across cultures using the Teachers' Ten Statements Test". Teaching and Teacher Education 27, 579-588.

Kline, Rex B. (2011) Principles and practice of structural equation modeling. Guilford Press.

König, Johannes and Martin Rothland (2017) "Motivations that affect professional knowledge in Germany and Austria”. In H. M. G. Watt, P. W. Richardson and K. Smith, eds. Global perspectives on teacher motivation, 162-188. Cambridge, UK: Cambridge University Press.

Lin, Emily, Quingmin Shi, Jian Wang, Shaoan Zhang, and Liu Hui (2012) "Initial motivations for teaching: comparison between preservice teachers in the United States and China". Asia-Pacific Journal of Teacher Education 40, 3, 227-248.

Müller, Karin, Roberta Alliata, and Fabienne Benninghoff (2009) "Attracting and retaining teachers: a question of motivation". Educational Management Administration and Leadership 37, 5, 574-599.

Nesje, Katrine, Christian Brandmo and Jean-Louis Berger (2018) "Motivation to become a teacher: a Norwegian validation of the Factors Influencing Teaching Choice scale". Scandinavian Journal of Educational Research 62, 6, 813-831.

Niemi, Hannele (2016) "The societal factors contributing to education and schooling in Finland". In H. Niemi, A. Toom, and A. Kallioniemi, eds. Miracle of education: the principles and practices of teaching and learning in Finnish schools, 23-40. Rotterdam: Sense Publishers.

Niemi, Hannele, Auli Toom and Arto Kallioniemi, eds. (2016) Miracle of education: the principles and practices of teaching and learning in Finnish schools. 2nd rev. ed. Rotterdam: Sense Publishers.

OECD (2018a) Education at a glance 2018: OECD Indicators. Available online at $<\mathrm{https} / / \mathrm{read}$. oecd-ilibrary.org/education/education-at-a-glance-2018/reference-statistics_eag-2018-35en\#page8 $>$. Accessed on 10.07.2019.

OECD (2018b) PISA 2015 results in focus. Available online at $<$ https://www.oecd.org/pisa/pisa-2015results-in-focus.pdf>. Accessed on 10.07.2019.

OECD (2018c) Teaching in focus \#22. Who wants to become a teacher and why? Available online at $\quad<$ https://read.oecd-ilibrary.org/education/who-wants-to-become-a-teacher-and-why_ d6a81156-en\#page1>. Accessed on 10.07.2019.

OECD (2020) TALIS 2018 results (Volume II): Teachers and school leaders as valued professionals. TALIS, OECD Publishing. Available online at $<$ https://www.oecd.org/publications/talis-2018results-volume-ii-19cf08df-en.htm>. Accessed on 10.04.2020.

OECD Statistics (2016) Available online at $<$ https://stats.oecd.org/>. Accessed on 10.07.2019.

Paronen, Paula and Olga Lappi (2018) Finnish teachers and principals in figures. Helsinki: Finnish National Agency for Education. Available online at $<$ https://www.oph.fi/download/189802 finnish_teachers_and_principals_in_figures.pdf $>$. Accessed on 10.07.2019.

PISA 2015 tulemuste infomaterjal (2016) [PISA 2015 performance information material.] The Ministry of Education and Research. Available online at $<$ https://www.hm.ee/sites/default/files/pisa kokkuvotlik_infomaterjal.pdf $>$. Accessed on 15.07.2019.

Reimer, David and Hans Dorf (2014) "Teacher recruitment in context: differences between Danish and Finnish beginning teacher education students". Scandinavian Journal of Educational Research $58,6,659-677$. 
Richardson, Paul W. and Helen M. G. Watt (2006) "Who chooses teaching and why? Profiling characteristics and motivations across three Australian universities". Asia-Pacific Journal of Teacher Education 34, 1, 27-56.

Sarv, Ene-Silvia (2014) “A status paper on school teacher training in Estonia”. Journal of International Forum of Educational Research 1, 2, 106-158. Available online at $<\mathrm{http}$ ://ejournal.ifore.in/ December\%202015/7.\%20IFORE\%20Ene-Silvia\%20Sarv.pdf $>$. Accessed on 10.01.2019.

Taimalu, Merle, Piret Luik, Ritva Kantelinen, Airi Niilo, and Airi Kukk (2013) "Factors Influencing Teaching Choice among first year student teachers in Estonia and Finland". In European Conference on Educational Research September 9-13 2013, Istanbul Turkey.

Taimalu, Merle, Piret Luik, and Karin Täht (2017) "Teaching Motivations and Perceptions during the First Year of Teacher Education in Estonia”. In H. M. G. Watt, P. W. Richardson, and K. Smith, eds. Global perspectives on teacher motivation, 189-219. Cambridge: Cambridge University Press.

Taimalu, Merle, Krista Uibu, Piret Luik, and Äli Leijen (2019) Õpetajad ja koolijuhid elukestvate õppijatena. OECD rahvusvahelise õpetamise ja õppimise uuringu TALIS 2018 uuringu tulemused, 1. osa. [Teachers and school leaders as lifelong learners. The OECD International Study on Teaching and Learning TALIS 2018 results, volume I. Estonian report]. Available online at $<$ https://www.hm.ee/sites/default/files/talis_eesti_raporti_i_osa.pdf $>$. Accessed on 10.04.2020.

Tirri, Kirsi (2014) “The last 40 years in Finnish teacher education”. Journal of Education for Teaching $40,5,600-609$.

Uztosun, Mehmet S. and Ece Z. Topkaya (2017) “A cross-national study into pre-service EFL teachers' career choice motivations in Germany, Japan, and Turkey". Asian EFL Journal 19, 2, 83-110.

Valk, Aune (2016) Õpetajaameti atraktiivsus. [Attractiveness of the Teaching Authority]. Tartu: Haridus- ja Teadusministeerium. Available online at $<$ https://www.hm.ee/sites/default/files/ hmin_opetaja_atraktiivsus.pdf $>$. Accessed on 17.08.2019.

Watt, Helen M. G. and Paul W. Richardson (2007) "Motivational factors influencing teaching as a career choice: development and validation of the FIT-Choice Scale". The Journal of Experimental Education 75, 3, 167-202.

Watt, Helen M. G. and Paul W. Richardson (2012) “An introduction to teaching motivations in different countries: comparisons using the FIT-Choice scale". Asia-Pacific Journal of Teacher Education 40, 3, 185-197.

Watt, Helen M. G., Paul W. Richardson, Uta Klusmann, Mareike Kunter, Beate Beyer, Ulrich Trautwein and Jürgen Baumert (2012) "Motivations for choosing teaching as a career: an international comparison using the FIT-Choice scale". Teaching and Teacher Education 28, 791-805.

Watt, Helen M. G., Paul W. Richardson, and Kari Smith (2017) "Why teach? How teachers' motivations matter around the world". In H. M. G. Watt, P. W. Richardson and K. Smith, eds. Global perspectives on teacher motivation, 1-21. Cambridge, UK: Cambridge University Press. 